Article

\title{
Climate-Smart Agriculture: Sleeping Beauty of the Hungarian Agribusiness
}

\author{
Kinga Biró ${ }^{1, * \mathbb{D}}$, Mária Szalmáné Csete ${ }^{1} \mathbb{D}$ and Bálint Németh ${ }^{2}$ \\ 1 Department of Environmental Economics, Faculty of Economic and Social Sciences, Budapest University of \\ Technology and Economics, 1111 Budapest, Hungary; csete.maria@gtk.bme.hu \\ 2 Department of Electric Power Engineering, Faculty of Electrical Engineering and Informatics, \\ Budapest University of Technology and Economics, 1111 Budapest, Hungary; nemeth.balint@vet.bme.hu \\ * Correspondence: biro.kinga@gtk.bme.hu
}

Citation: Biró, K.; Szalmáné Csete, M.; Németh, B. Climate-Smart Agriculture: Sleeping Beauty of the Hungarian Agribusiness. Sustainability 2021, 13, 10269. https:/ / doi.org/10.3390/su131810269

Academic Editor: Roberto Mancinelli

Received: 23 July 2021

Accepted: 10 September 2021

Published: 14 September 2021

Publisher's Note: MDPI stays neutral with regard to jurisdictional claims in published maps and institutional affiliations.

Copyright: (c) 2021 by the authors. Licensee MDPI, Basel, Switzerland. This article is an open access article distributed under the terms and conditions of the Creative Commons Attribution (CC BY) license (https:// creativecommons.org/licenses/by/ $4.0 /)$.

\begin{abstract}
Climate change and agriculture interact with each other in many ways and have a complex impact. The agriculture sector needs to be prepared to adapt to the expected effects of climate change, and emphasis must be placed on prevention to achieve emission reduction targets. The research explores the current situation in the agricultural sector, the risks of climate change, as well as the Climate-Smart Agriculture (CSA) solutions that appear at Hungarian agribusiness. Examining the climate innovation activities of farms shows a coherence of the practical application. The research is based on a questionnaire survey of Hungarian agribusiness and the country directorates of the National Chamber of Agriculture. The investigation confirmed that although farmers are susceptible to Agri-Innovation, they only partly exploit the potential of digitalization. For agriculture, the spread of agricultural digitalization and technology transfer is an excellent opportunity to increase agricultural production, maintain and improve its market position, and increase its digital maturity, which can also enhance the integration of climate innovation and sustainability aspects supporting the green economic development.
\end{abstract}

Keywords: climate change; agribusiness; Agri-Innovation; climate innovation; Climate-Smart Agriculture (CSA); sustainable development

\section{Introduction}

Climate change is one of the most critical economic and social challenges of the 21st century, and its effect on environmental sustainability is confirmed by several documents [1-3]. The Paris Agreement adopted in 2015 is a milestone to deal with the core problems of climate change, as it has accelerated the transition to a low-carbon economy. Emissions of anthropogenic greenhouse gases are increasing globally, and a significant part of this can be attributed to the corporate sector. There have been several initiatives to achieve carbon neutrality, with which companies can also express their social responsibility. The 2019 UN Climate Summit urges the development and implementation of concrete measures in the field of climate change at various territorial levels. According to the latest IPCC Special Report on Climate Change and Land, the primary GHGs between land and the atmosphere is carbon dioxide $\left(\mathrm{CO}_{2}\right)$, methane $\left(\mathrm{CH}_{4}\right)$, and nitrous oxide $\left(\mathrm{N}_{2} \mathrm{O}\right)$. Activities accounted for approximately $23 \%$ of global anthropogenic GHG emissions over the period 2007-2016 [3]. The IPCC's Sixths Assessment Report clearly shows that in the coming decades, climate changes will increase in all regions. There will be increasing heat waves, longer warm seasons, and shorter cold seasons. At $2{ }^{\circ} \mathrm{C}$ of global warming, heat extremes would more often reach critical tolerance thresholds for agriculture. The Sixth Assessment Report provides a more detailed regional assessment of climate change for the first time. The report also emphasizes that human action still has the potential to impact climate change. Carbon dioxide is the main driver of climate change, even as other GHGs affect climate. Limiting especially methane, which comes from agricultural sources, could 
have benefit in climate protection [2]. The need for adaptation depends primarily on the extent of climate change, geographical location, and available economic, environmental, and social resources.

Research on adaptation measures has become one of the most dynamically developing research directions in the field of climate change [4-8]. The transfer of good practices and the assessment of the factors influencing farmers' decisions are both important. Adaptation to the effects of climate change, environmental research, and best practices are the subject of many scientific papers and research studies. Scientific findings suggest that effects on agriculture can take very heterogeneous directions, especially in crop production [9-12] and animal husbandry [13]. A study was focusing on the regional impacts of climate change and local characteristics of agriculture in Europe [14].

Promoting innovation and sustainable development is a key element in European development policies. Innovation has a pivotal role to play in promoting a resource-efficient, greener, and more competitive economy. The European Commission is increasingly promoting the commitment to sustainable agriculture and food production in the EU, which is reflected in the European Green Deal. Our research is in line with the objectives of the EU's Common Agricultural Policy, contributing to the environmental sustainability of agricultural production. The European Environment Agency's 2019 report [15] also draws attention to the sector's potential for adaptation. The new EU Adaptation Strategy, published at the end of February 2021 (COM/2021/82 final), focuses on the implementation of a climate-resilient European Union, which is also in line with the EU's green economic development and sustainability efforts. The main objective of the strategy is to make the EU a resilient society to the effects of climate change by 2050, in which the implementation of climate innovation efforts in rural areas, as well as measures and developments related to the agricultural economy, can play a key role. Innovations related to the concept of climate innovation are typically associated with mitigation activities but can also be created as adaptation activities.

According to the Digital Economy and Society Index (DESI), Hungary ranks 21st among 28 EU Member States [16]. The country's performance has improved in recent years at a pace in line with the EU average. Most companies do not take advantage of the potential of digital technologies such as cloud-based systems and big data technology. A community survey on ICT usage and eCommerce in Enterprises (which is also the basis of DESI) is based on enterprises with 10 persons or more and does not cover the agriculture sector. Hungary's innovation performance lags far behind the European Union average. The results of the European Innovation Scoreboard in 2020 show that innovation performance continues to improve across the EU: Sweden has the best innovation performance in the EU, followed by Finland, Denmark, and the Netherlands. Hungary belongs to the group of moderate innovators; the value of its aggregate innovation indicator reaches $66.4 \%$ of the EU average [17]. The results highlight that innovation can play a significant role to increase the EU's global competitiveness and tackle the COVID-19 pandemic. To help repair the economic and social damage caused by the coronavirus pandemic, the EU has set up the Recovery and Resilience Facility, which provides an opportunity for member states to mitigate the effects of COVID-19 and return to growth and make the EU greener, more digital, and resilient.

The possible pathways of digital transformation have a growing importance in European and the Hungarian agricultural policy as well [18]. To increase agricultural digitalization and competitiveness, Hungary's Digital Agriculture Strategy was born in 2019, which aims at the spread of digital solutions and precision farming in agricultural production. Modern technologies contribute to increasing food security and the profitability of agricultural production. Digitalization can strengthen all three dimensions of sustainability: it can (1) increase farmers' income; (2) reduce production risks and environmental pressures; and (3) diminish critical labor shortages in agriculture [19]. The Digital Agriculture Academy initiative was born to develop the digital maturity level of Hungarian agriculture, which, after registration on the website of the National Chamber of Agriculture, helps interested 
farmers to get acquainted with digitization and its applicability, thus contributing to the market advantage of a business.

Hungary lies in the Carpathian Basin, and thus its topography and climatic conditions are favorable for agricultural production, but it is also vulnerable due to its unique characteristic, as the country's territory is located on the border of three climatic areas [20-22]. Several measures and activities can be implemented to adapt agriculture to climate change [23-27]. Regarding Hungarian agriculture, studies draw attention to the importance of adaptation to the expected effects of climate change [28-35]. In the case of agricultural business, the literature is often limited to the effects of climate change or greenhouse gas emissions and reductions from agriculture [36-39] and focuses on Climate-Smart Agriculture (CSA) [40-44]. Greenhouse gas emissions from the Hungarian agricultural sector accounted for 1.9\% of the European Union's total emissions in 2019. The land-use rate is well above the Western European average. Almost $60 \%$ of the country's territory is under agricultural cultivation and the most significant branch of cultivation is arable land, which accounts for almost four-fifths of the area. Agriculture contributed $4.1 \%$ to the gross domestic product (GDP) in 2020 [45].

In Hungary, the agricultural sector is the third largest carbon-emitting sector: in 2018 , it contributed $17.5 \%$ to its total emissions. This sector accounts for $81 \%$ of domestic nitrous oxide emissions (land use and fertilizers) and 37\% of methane emissions (animal husbandry). Greenhouse gas emissions are unequal by region due to different spatial and production conditions. Emissions are above average in Central Transdanubia, the Southern Great Plain, and Western Transdanubia, but the Northern Hungary region lags far behind the average. The largest regions of the Great Plain stand out in agricultural production: at current basic prices, they account for almost half of the total output (46\%), while the Budapest and Pest regions together contribute $7.4 \%$ and Northern Hungary $7.6 \%$. Based on the gross value added per 1 hectare of agricultural area, agricultural productivity was highest in 2019 in the Northern and Southern Great Plain and Western Transdanubia, while it was lowest in Northern Hungary and the Budapest and Pest regions. Regions with previously low values lagged even further behind, with regional disparities widening overall in terms of productivity. In 2020, the volume of animal husbandry decreased by $1.3 \%$ and crop production by $3.3 \%$. The total volume was thus $2.2 \%$ lower than in 2019 .

Overall, it can be stated that the agricultural sector is extremely important for Hungary, but we are talking about a very sensitive sector exposed to climate change; therefore, the application of emission reduction and adaptation measures is essential. The research aims to provide an insight into the relationship between CSA solutions, tools, and climate change in Hungarian agribusiness, presenting smart tools and concepts emerging in business that are closely related to the process of adaptation to and mitigation of climate change. Research can contribute to sustainable agriculture and support a key economic policy such as increasing competitiveness, added value and income-generating capacity of agriculture and in strengthening the agribusiness digitalization.

\section{Materials and Methods}

In our research, we evaluated the climate innovation efforts of the agriculture sector and the CSA activity of agribusiness based on a questionnaire survey where we questioned various actors in the Hungarian agricultural sector. Two online questionnaire-based surveys were carried out to analyze the issue in a complex way from two different aspects. At the organizational level, we surveyed the Hungarian agribusinesses. The number of respondents was 50 . The survey covered three major topics, namely

1. Company operations related to climate change: problems, reports and programs, risk assessment, monitoring, climate protection activities, and practice (both mitigation and adaptation).

2. Climate-Smart Agriculture: knowledge, definition, concepts, tools, practice, frequency of application, barriers of the application, willingness to use, self-development. 
3. Digital Agricultural Academy: knowledge, application, utilization, advantages related to the materials and training.

The survey included structured, closed questions but at the end of some questions we provided an 'other' option. We examine the awareness of the concept of Climate-Smart Agriculture from several perspectives. Public actors have a major role to play in education and knowledge transfer. In the case of the institutional community, we wanted to get a general picture of the topic, and an important aspect was the comparability of the two communities. From an institutional point of view, we have asked the country directorates of the National Chamber of Agriculture. We contacted county directors and training referents. The online survey consisted of only five short questions which covered the same topic as it has shown in the 2nd major topic at organizational level: Climate-Smart Agriculture definition, concept awareness, implementation of the methodology and the last question concerned the main barriers to the use of tools. We have reached 36 individuals with a willingness to respond of $34 \%$ so the number of respondents was 12 . The task of the National Chamber of Agriculture is to provide professional support, advice, and knowledge transfer to domestic companies. They operate a counseling center, launch vocational training, and operate the Digital Agricultural Academy.

\section{Results}

We assessed the Agri-Innovation and CSA activities of business according to the three dimensions of sustainability. The framework can be applied in general to the evaluation of the CSA activities of businesses engaged in agricultural activities and can contribute to the dissemination of good practices and the displacement of farmers' Agri-Innovation activities, thus supporting the implementation of common policy objectives.

\subsection{Climate-Smart Agriculture (CSA) Tools}

By CSA tools we mean a collective concept that includes all technologies, approaches, measures for mitigation and adaptation, promoting the establishment of climate-friendly and climate-resilient agriculture. The number of smart devices is on an ever-increasing trend due to innovation. The interpretation of CSA tools can be narrowed down to different technological innovations or novel uses of already-existing technologies. These tools generally consider traditional good agricultural practices and thus build on them to create innovations. Based on the survey, we identified 27 CSA tools appearing in the examined companies, which were classified into six groups. In the survey, 18 CSA tools were listed, and the respondents were free to list other tools as well. The above list does not cover the whole CSA tools, the primary consideration in delimiting the elements was mostly to present the diversity of the tools through which we want to provide an insight into the diverse world of CSA technologies. Based on our research so far, the following categories have been developed: (1) Robotization: primarily innovations related to crop production, such as the use of automatic harvesters or robotic weed and pathogen control. (2) Bio innovation: using biological/chemical technologies to help reduce GHG emissions from agriculture and adapt to climate change, such as plant breeding, the development of new seeds, or the development of artificial meat. (3) Smart monitoring system: smart systems continuously monitor and analyze, e.g., the behavior of farm animals, giving farmers a much more accurate picture of the physical condition of their animals. (4) Big Data analyzes and identifies climate trends and makes a more accurate forecast. (5) Precision agriculture: this can effectively make agriculture climate-intelligent by reducing its impact on the environment. (6) IoT (Internet of Things): microsensors that are smart technologies and can transmit various measured data (e.g., soil moisture content) to other online devices.

Agricultural innovation can be classified in several ways. Further developing the areas of innovation often mentioned in agriculture [46,47], we divided them into six categories: (1) responsible innovation, (2) technological innovation, (3) social innovation, (4) organizational innovation, (5) green innovation, (6) management innovation. According to the different types of innovation, in connection with the three basic dimensions of 
sustainability (environmental, social, and economic pillars), we analyzed the CSA solutions used in the study area in a sustainability impact assessment matrix (Table 1), which included those new or improved technologies, practices and processes that can have a real positive impact on one or more dimensions of sustainability.

Table 1. The identified CSA tools from the perspective of sustainability.

\begin{tabular}{|c|c|c|c|}
\hline Sustainability Dimensions & Type of Innovation & $\begin{array}{c}\text { Identified CSA Tools for } \\
\text { Mitigation }\end{array}$ & $\begin{array}{c}\text { Identified CSA Tools for } \\
\text { Adaptation }\end{array}$ \\
\hline \multirow[b]{2}{*}{ Environmental dimension } & Green innovation & $\begin{array}{l}\text { Organic growing solution, } \\
\text { agrotechnology development, } \\
\text { smart fleet of vehicles, } \\
\text { eco-aquaculture techniques, } \\
\text { integrated manure treatment, } \\
\text { smart composting }\end{array}$ & $\begin{array}{l}\text { Environmental sensors and } \\
\text { data loggers, soil sensor, bird } \\
\text { alert, soil performance } \\
\text { monitoring system, bio } \\
\text { innovation tools }\end{array}$ \\
\hline & Technological innovation & $\begin{array}{l}\text { Organic growing solution, } \\
\text { robotization, smart fleet of } \\
\text { vehicles, integrated manure } \\
\text { treatment, integrated plant } \\
\text { management, water-saving } \\
\text { smart irrigation systems, } \\
\text { smart composting, toxic gas } \\
\text { level monitoring }\end{array}$ & $\begin{array}{l}\text { Stock management system, } \\
\text { drought monitoring system, } \\
\text { optimising fertilizer use, } \\
\text { livestock activity meter and } \\
\text { monitoring, environmental } \\
\text { sensors and data loggers, soil } \\
\text { sensor, bird alert, soil } \\
\text { performance monitoring } \\
\text { system, malware monitoring } \\
\text { system, robotized weed } \\
\text { control, robotized pest control, } \\
\text { automatic pick-up machines, } \\
\text { use of drones, bio innovation } \\
\text { tools, digital farm } \\
\text { management }\end{array}$ \\
\hline \multirow[b]{2}{*}{ Social dimension } & Social innovation & $\begin{array}{c}\text { Organic growing solution, } \\
\text { robotization, smart fleet of } \\
\text { vehicles }\end{array}$ & Bio innovation tools \\
\hline & Responsible innovation & $\begin{array}{l}\text { Organic growing solution, } \\
\text { agrotechnology development, } \\
\text { smart fleet of vehicles, solar } \\
\text { irrigation system regulation, } \\
\text { feed management, integrated } \\
\text { manure treatment, integrated } \\
\text { plant management, } \\
\text { water-saving smart irrigation } \\
\text { systems, smart composting }\end{array}$ & $\begin{array}{l}\text { Drought monitoring system, } \\
\text { environmental sensors and } \\
\text { data loggers, soil sensor, soil } \\
\text { performance monitoring } \\
\text { system, climate-smart } \\
\text { livestock farming, bio } \\
\text { innovation tools }\end{array}$ \\
\hline \multirow{2}{*}{ Economic dimension } & Management innovation & Feed management & $\begin{array}{l}\text { Stock management system, } \\
\text { weather forecast-based } \\
\text { activity management, } \\
\text { climate-smart livestock } \\
\text { farming, digital farm } \\
\text { management }\end{array}$ \\
\hline & Service innovation & Agrotechnology development & $\begin{array}{l}\text { Drought monitoring system, } \\
\text { livestock activity meter and } \\
\text { monitoring, malware } \\
\text { monitoring system }\end{array}$ \\
\hline
\end{tabular}

Based on the survey, a total of 27 CSA tools were identified that strengthen the environmental dimension the most. Based on the sustainability assessment of the businesses engaged in agricultural activities in the studied area, it can be stated that the CSA tools used to support mitigation can strengthen the environmental and social pillar of sustainability the most. The environmental dimension proved to be the strongest based on the evaluation. 
The identified solutions can strengthen responsible innovation within the social pillar, which means predicting impacts at all levels of agriculture [48], considering the wider impacts on society, delivering social benefits, addressing negative impacts, and thus we can talk about a key innovation in terms of smart management. A low GHG economy can contribute to social well-being. Viability is the key to sustainability, and this goal is supported by the vision of decarbonization, yet, in our assessment, social innovation is the least supported leg. Based on the evaluation of the tools supporting adaptation, it can be concluded that the applied CSA solutions can strengthen the environmental pillar of sustainability the most, and economies of scale seem to prevail, such as the condition of precision agriculture is the appropriate economic size.

During the evaluation, CSA tools supporting mitigation were first identified, as shown in Table 2a below, which lists all the identified tools. During the evaluation, we used the evaluation criterion built along with the following system of principles, during which the values " 4 ", " 3 ", " 2 ", " 1 " and " 0 " are displayed (Table $2 c$ ). The evaluation matrix thus formed can be easily interpreted. Among the mitigation-oriented solutions, the prevalence of agrotechnology development, integrated manure treatment and robotization can be highlighted as positive; however, the truly innovative solutions such as a smart fleet of vehicles and the widespread use of solar energy were not typical. In general, the use of stock management and drought monitoring systems, livestock activity monitoring systems were not typical of the study.

Table 2. Evaluation of CSA tools in the examined companies: (a) the identified CSA tools supporting mitigation; (b) the identified CSA tools supporting adaptation; (c) evaluation criterion.

a. The Identified CSA Tools Supporting Mitigation

\begin{tabular}{|c|c|}
\hline Identified CSA Tools & Mitigation \\
\hline Organic growing solution & 1 \\
\hline Agrotechnology development & 3 \\
\hline Smart fleet of vehicles & 2 \\
\hline Feed management & 1 \\
\hline Integrated manure treatment & 2 \\
\hline Eco-aquaculture techniques & 1 \\
\hline Integrated plant management & 3 \\
\hline Smart composting & 1 \\
\hline Robotization & 3 \\
\hline \multicolumn{2}{|c|}{ b. The identified CSA tools supporting adaptation } \\
\hline Identified CSA tools & Adaptation \\
\hline Stock management system & 2 \\
\hline Drought monitoring system & 2 \\
\hline Optimising fertilizer use & 1 \\
\hline Livestock activity meter, monitoring & 3 \\
\hline Environmental sensors and data loggers & 3 \\
\hline Weather forecast-based activity management & 4 \\
\hline Soil sensor & 0 \\
\hline BirdAlert & 0 \\
\hline Soil performance monitoring system & 2 \\
\hline Climate-smart livestock farming & 0 \\
\hline Smart walware monitoring system & 2 \\
\hline
\end{tabular}


Table 2. Cont.

\begin{tabular}{cc}
\hline Robotized weed control & 0 \\
\hline Robotized pest control & 0 \\
\hline Automatic pick-up machines & 0 \\
\hline Use of drones & 3 \\
\hline Bioinnovation tools & 0 \\
\hline Digital farm management & c. Evaluation criterion \\
\hline & Mentioned at once \\
\hline 1 & Mentioned at 2-5 times \\
\hline 2 & Mentioned at 6-9 times \\
\hline 4 & At least 10 mentions \\
\hline 0 & NR
\end{tabular}

After mitigation-oriented solutions, some CSA solutions supporting adaptation were examined during the study. The domestic application of adaptation-oriented tools can improve both sectoral and regional adaptation and Agri-Innovation capacity. Observing the whole sample (Table $2 \mathrm{~b}$ ), the number of adaptation solutions exceeds the tools supporting mitigation, thus indicating its importance. Improving food security, striving for sustainable farming, and increasing the number of organic farms is a key element in adapting to climate change. Weather forecast-based activity management systems, environmental sensors and data loggers, and smart monitoring systems are among the solutions supporting adaptation, reflecting the exposure and sensitivity challenges, of which the changing rainfall distribution and water shortages caused by heatwaves are closely related to domestic agriculture' sustainability challenges. Evaluating the results, weather forecasting systems, digital farm management, the use of sensors and drones, and animal activity measurement systems have emerged as highlights. The biggest shortcoming of CSA solutions is in the field of sensors, robots, and bio innovation tools.

\subsection{Quantitative Analysis}

The first part of the questionnaire focused on the characteristics of the companies. The respondents covered the whole country, all responses came from the seven Hungarian NUTS-2 regions, while most companies comes from the Transdanubia region (80\%). The size and production potential of the agricultural area of the regions are different, so their output shows an unequal picture. Compared to its agricultural area, Southern Transdanubia accounts for a significantly larger share of the national grain output, Western and Southern Transdanubia the share of wine, and Central and Western Transdanubia the share of other crop products. Based on the specific gross value-added calculated for the agricultural area, the productivity in 2019 was the highest in the Western Transdanubia in addition to the Great Plain region. In terms of farm size, $60 \%$ of respondents are microenterprises, 30\% Small and Medium-sized Enterprises (SMEs) and the remainder 10\% are Multinational Enterprises. Regarding the occupation of the respondents, $40 \%$ are mixed farming, i.e., both crop and livestock production, $44 \%$ are engaged in only crop production, and $6 \%$ in animal husbandry. Answers were also received from businesses with other activities but related to the agricultural economy (e.g., forestry, beekeeping); $96 \%$ of agribusiness have already experienced a change in the company's operations and production in recent years, which is due to climate change. The highest proportion of respondents experienced reduced productivity due to drought periods, but in addition, half of the respondents experienced reduced productivity due to pests, diseases, heatwaves, and storm damage, water supply problems, and decrease in fertilizer efficiency (Figure 1). 


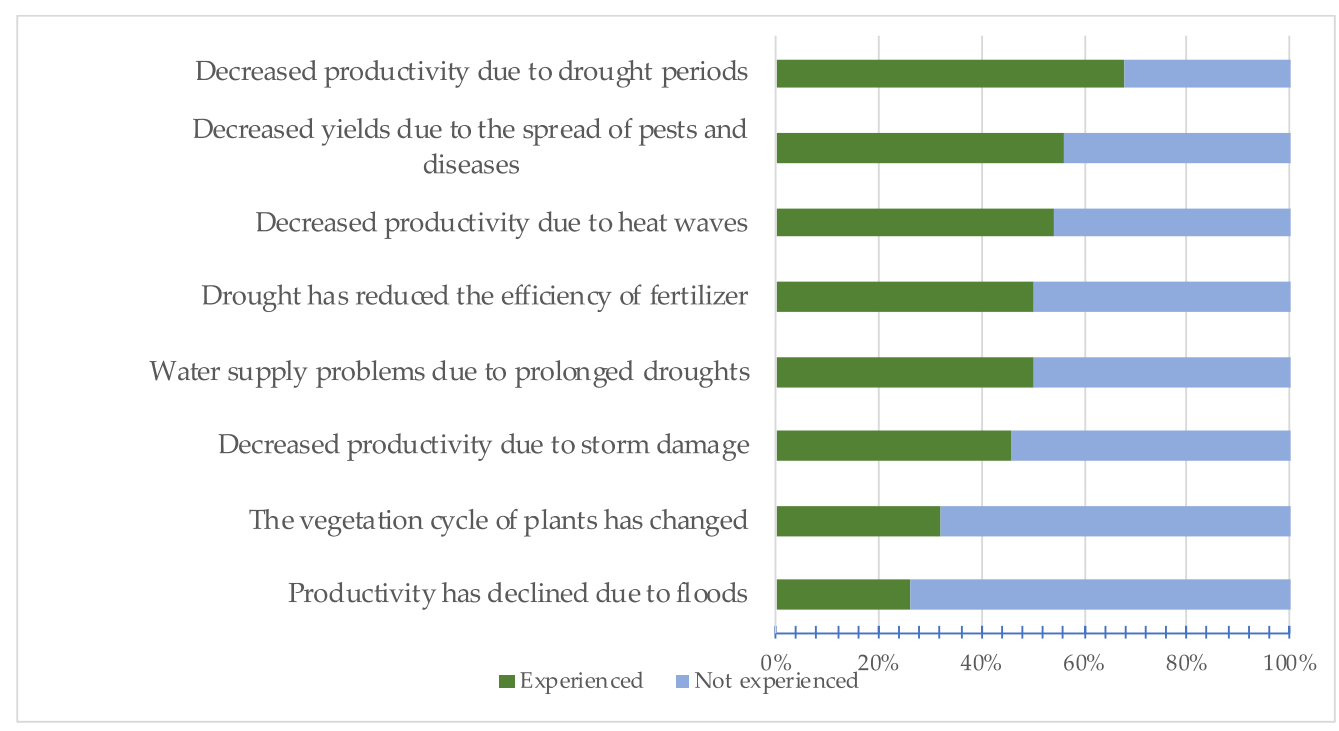

Figure 1. Climate-related impacts experienced in the Hungarian agribusiness.

The answers also illustrate why it is important to examine the relationship between agriculture and climate change, and why it is important to address Agri-Innovation and various innovative tools such as Climate-Smart Agriculture. The concept of CSA is known to half of those working in the institutional sector, while nearly a quarter of the companies surveyed are familiar with it. The National Chamber of Agriculture's education portfolio includes an online curriculum on the digital agricultural economy that would also provide a good foundation for the CSA topic. Chamber staff $(80 \%)$ and business $(72 \%)$ agree that the key element of the CSA is to ensure food security; that is, to associate the concept of the CSA with an approach that helps transform agriculture to meet the food needs of the Earth's population, even in the age of climate change.

For companies, we asked several questions about CSA. One question concerned which of the three pillars of the CSA (productivity, mitigation, adaptation) were mainly associated with the concept; $44 \%$ of respondents indicated the development of sustainable agricultural production, while $20 \%$ indicated a reduction in GHG emissions from agriculture and 10\% an adaptation. The responses reflect the impact of climate change on farmers, which in many cases harms production, reduces profits, and is therefore open to innovation and development. However, the phenomena are not yet linked because in only 11 cases was the concept of CSA associated with the treatment of all three problems. The direct risks of climate change are assessed by $56 \%$ of businesses, of which in 4 cases the risk assessment is an integral part, and in the other 24 cases, a few climate risk factors are monitored.

The most obstacles are the lack of financial resources $(60 \%)$ and the lack of skilled labor (Figure 2). Only $18 \%$ of the respondents would be willing to finance CSA tool on their own, while $58 \%$ of the respondents would be finance CSA tool only with financial support and the remaining $24 \%$ of the respondents do not want to use CSA tool.

Digital Agricultural Academy (DAA) supports interested farmers to get acquainted with digitization, introducing the basic issues, how to access opportunities and smart tools. $42 \%$ of the surveyed companies have heard about the materials but do not use them. Previously, only one company used the available curriculum, and it should be emphasized that $58 \%$ of the respondents did not even hear about it, while their application could be of paramount importance for the competitiveness of the sector. 


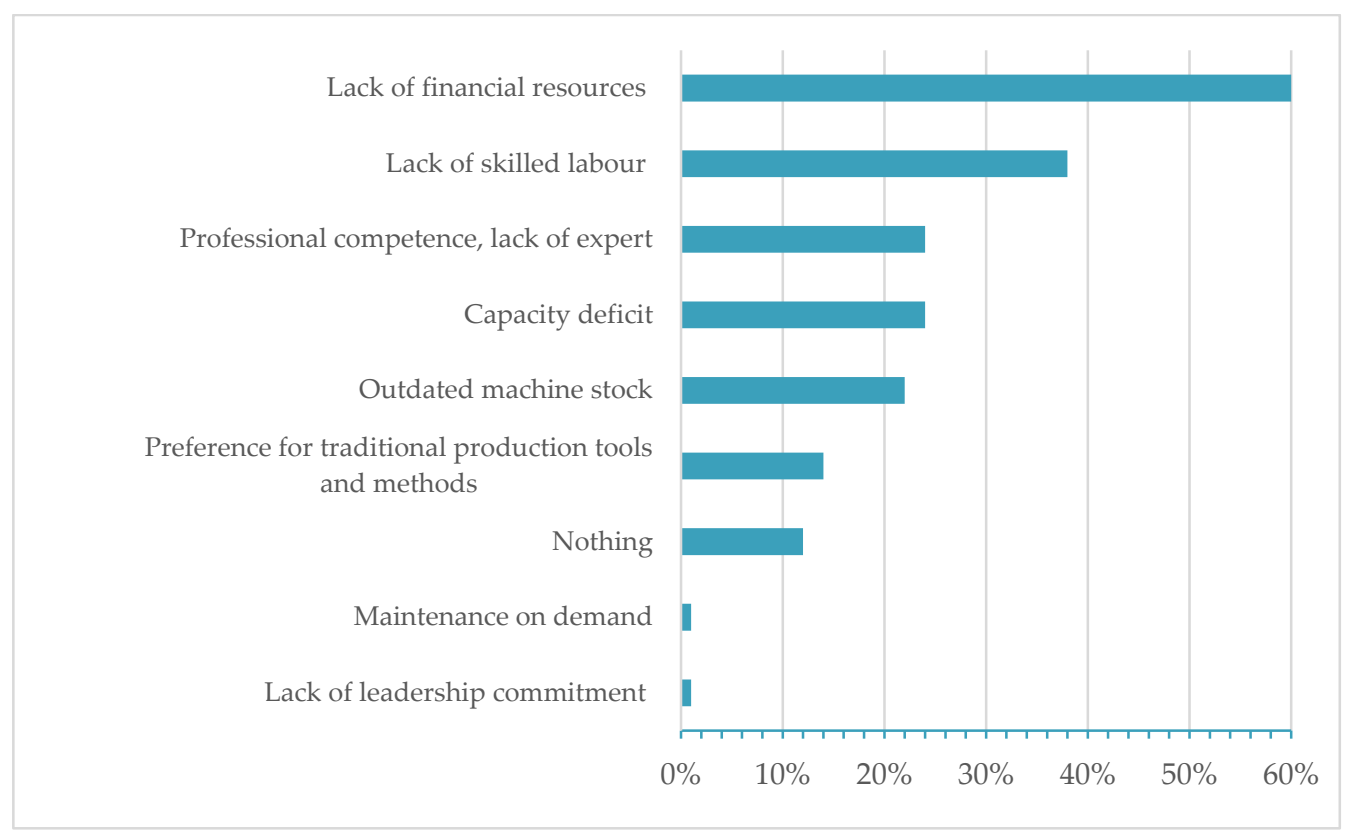

Figure 2. The main barriers to the implementation and application of the CSA tools.

Our research confirmed that farmers in the study area are susceptible to Agri-Innovation, but only partially exploit the potential of digitalization, especially in the case of climate innovation solutions, as they do not have sufficient experience and practical knowledge in the implementation and operation of the innovation tool. Although $76 \%$ of the respondents are interested to finance CSA tool, in spite of that they are consider the lack of financial resources and the shortage of skilled labor to be the main obstacles to the implement of CSA tools.

\section{Discussion}

The effects of climate change are most visible in economic processes that are closely linked to the environment, so they have a significant impact on agriculture. Hungary faces several challenges due to changing climatic conditions so adaptation to climate change can also be interpreted as one of the critical points of long-term sustainability. The number of adaptation activities is on an increasing trend, with farmers taking steps to prevent the expected effects of climate change, such as changing sowing times, precision farming and more efficient species, but it is important to note that farms have different inputs, climate factors and soil characteristics, so it is necessary to apply adaptation measures that differ between regions, considering local characteristics [11].

Innovation is associated with several stakeholders especially considering relevant business, but the public and a community can be also innovating. During innovation, the company uses new technologies, builds a new organization, produces a new product, and uses new sales channels. Agricultural innovation can be interpreted by extending it to the whole of agriculture [49-51]. Efficiency is of key importance not only from a sectoral but also from a social point of view in the field, as agricultural innovations can effectively contribute to the implementation of sustainable agriculture [52], which has increasing importance in the age of digital transition. The EU's rural development program for the programming period 2014-2020 also emphasized the role of innovationrelated measures in improving the livability of rural areas. Society is also an important driver of innovation, such as agricultural production and agri-food. Among the social factors, the qualifications of farmers and their openness to innovation are decisive. The European Innovation Partnership for Agricultural Productivity and Sustainability (EIPAgri) increases the productivity and sustainability of agricultural and forestry sectors and help them to adapt to the expected effects of climate change. The partnership is responsible 
for disseminating and transferring knowledge about innovation and agriculture, shaping farmers' attitudes, developing innovative approaches, and identifying innovative solutions that can help increase the competitiveness of the agricultural economy in the European Union [53].

The UN forecasts that the world's population will grow by a third by 2050, while Hungary's population is expected to decline. If the uphill trend in incomes and consumption continues, the FAO (Food and Agriculture Organization of the United Nations) estimates that agricultural production will need to increase by $60 \%$ by 2050 to meet future food and feed needs [54]. Adapting to climate change and reducing emissions is essential in achieving food security and agricultural development goals. Thus, agriculture must respond simultaneously to three challenges: (1) ensuring productivity and food security, (2) adapting to climate change, and (3) reducing GHG emissions [55-58]. The CSA seeks to address these three challenges while integrating the three dimensions of sustainable development. The goal of the CSA is to increase agricultural productivity and incomes in a sustainable manner, to develop adaptation and resilience to climate change, and to reduce and/or eliminate GHG emissions [56]. A CSA is not just a unique technology or practice that is generally applicable, but an approach that requires site-specific research to develop appropriate agricultural practice and technology.

CSA Country Profiles provide an overview of the agricultural challenges facing countries around the world and how the CSA can help them reduce GHG emissions and adapt to climate change [59]. Most of the profiles cover Latin America, as well as parts of Africa and South Asia, while only one European country is included in the country profiles. The World Bank also supports the concept of CSA and is committed to working with countries to achieve the CSA's triple goal. In 2020, 52\% of World Bank agricultural support was targeted at climate change adaptation and mitigation. The World Bank supports CSA projects in many countries around the world, such as lower-emission agricultural practices and institutions in China. In Uruguay, they are helping to make farms climate-friendly by investing in energy efficiency and improving soil management capacity for sustainable agriculture [60].

With the support of international organizations, civil initiatives have also emerged, such as the Global Alliance for Climate-Smart Agriculture helping to spread CSA by connecting stakeholders through an online platform. Global Alliance for Climate-Smart Agriculture creates partnerships to encourage actions that reflect an integrated approach to the three pillars of CSA. CSA Booster is a database to collect and share information on international cooperative climate initiatives driven by non-state actors like businesses and cities. It has over fifty partners in the EU and a partner for Global Alliance for ClimateSmart Agriculture initiatives, hosted by the FAO [54]. Globally, there are many projects and research in a support of CSA, but a review of the international literature clearly shows that so far only a few published research has been produced in Europe [61], so the present study can be considered as filling a gap in this respect. Agricultural practices and technologies are smart for the climate if they can deliver integrated benefits. For example, reduced tillage practices can increase production by improving soil quality, support mitigation by increasing carbon capture, and strengthen farmers' resilience to climate shocks such as drought and floods $[40,62,63]$.

CSA needs to be examined from an integrated perspective, combining innovative technologies, production impacts, insurance options and risk preferences. In line with the mitigation and adaptation objectives of climate change and the EU's green economy development and digitalization efforts, CSA solutions can also contribute to the implementation of the Hungarian sustainable agricultural economy and rural development as a new area of agricultural innovations and digitalization processes [64].

The research results underpin the importance of evidence-based local and regional assessments. Considering the local and regional CSA evaluations those remains scarce, especially compared to the national level. According to the policy side it is worth highlighting that the 2nd Hungarian National Climate Change Strategy (NCCS, 2017-2030) does 
not deal with the topic of digitalization or climate-smart agriculture as a significant and effective tool. There is a lack of CSA tools both in case of the National Decarbonization Strategy and the National Adaptation Strategy, which are two main parts out of the three of the 2nd National Climate Change Strategy. It would be forward-looking to integrate this aspect into the next review of the NCCS. The Digital Agriculture Strategy was born in 2019, which explains why these aspects have not come to the fore, while the digital transition has also accelerated. We recommend that the Digital Agriculture Strategy addresses the climate aspects.

In Hungary, in addition to the Digital Agricultural Academy, there are several possibilities for farmers to get acquainted with digitalization and innovation. The Academy has a particularly important role to play, and further similar initiatives and training diversification are needed to expand the knowledge of all workers in the sector. The Agricultural Knowledge and Information System (AKIS) in Hungary focuses on agricultural advisory services. AKIS provides for farmers relevant knowledge and networks in Agri-Innovations. The current Hungarian advisory and consultancy system has 4 types: (1) national level free advisory services, financed by the EU and domestic resources, (2) Farm Advisory System (FAS), (3) commercial consultancy, and (4) consultancy offered by input providers, private sector actors. Agricultural advisory activity has a tradition in Hungary and 1100 advisors provide advisory services in Hungary, and the Hungarian Chamber of Agriculture employs 610 village agronomists. The quality and methodology of knowledge transfer have developed dynamically in recent years [65]. Farmers can also apply for agricultural postgraduate courses, e.g., agricultural digitization engineer, precision agricultural management specialist, precision agricultural consultant. Agro Napló is a nationwide agricultural journal. It has been one of the most known media of Hungarian agriculture since 1996. The journal describes innovative practical solutions based on domestic and international research. It also monitors and publishes current events and application opportunities, and reports on agricultural events (professional events, conferences, trade fairs). There is a wider range of knowledge transfer possibilities in Hungary, but further digitization opportunities should be offered to farmers.

\section{Conclusions}

According to the IPCC Sixth Assessment Report, it is not entirely hopeless to impact the various climate change-related changes with diverse human actions. Agriculture is a significant field of possible action and there is an urgent need to develop and use different effective solutions. In the era of digitalization, the CSA activities can promote the transition towards sustainability; furthermore, it can support mitigation and adaptation-oriented activities to find hidden potential to achieve the set of climate change-related goals at the same time. In line with the European Union's ambitions for green economic development and climate neutrality, as well as its objectives of promoting sustainability and the digital transition, the issue of agricultural digitalization and Agri-Innovation is becoming increasingly important in agricultural policy. There are several climate innovation processes and projects and research in support of Climate-Smart Agriculture worldwide, but only a very few publicly available research has been produced in Europe, so this study can be considered to be filling a gap. Smart tools can contribute to mitigation goals, but the adaptation-related CSA activities are also essential to prepare for the expected effects of climate change. Based on our research, it can be emphasized that it is necessary to bring technological developments closer to farmers, support them in sustainable innovation investments and practical application. For domestic agriculture, the spread of agricultural digitalization and technology transfer is an excellent opportunity to increase agricultural production, maintain and improve its market position, and increase its digital maturity, which also supports the integration of climate innovation and sustainability aspects. There is a great potential for developing CSA tools to create sustainable agriculture, as it can support not only EU climate policy goals, but also national recovery and resilience-building plans, in line with green economic development goals and the digital transition. Based 
on the survey, 27 CSA tools were identified in Hungary, which, overall, strengthen the environmental dimension of sustainability the most. The economic pillar of sustainability can be considered an area of deficit.

Moreover, there is an urgent need for integrating the CSA goals into the agricultural policy, especially focusing on regional characteristic. Due to this CSA-oriented policy development, the regional resilience can be improved. The positive shift of business towards climate innovation can be encouraged by the transfer of good practices (even by presenting international examples), information, exchange of knowledge and experience (conferences, workshops, lectures, specialized training), and practical assistance for the introduction of smart devices. The different knowledge transfer options can play a pivotal role in fostering the digital transition in agriculture. Training, education, and retraining have a key role to play in achieving the common agricultural policy goals. Farmers need to be prepared for digitization so that they can flexibly manage change and keep pace with dynamic development. It is essential to shape the attitudes of small producers, to achieve their openness again, the proper transfer and application of digital knowledge, all of which contribute to the success of Hungarian agricultural digitalization. Based on our research the potential burdens and challenges can be defined. Consequently, numerous policyoriented recommendations can be made to improve the transitions towards sustainability considering the hidden potential related to Climate-Smart Agriculture (CSA). The present study contributes to filling the scientific gap as regards sustainability, digitalization, and innovation related to climate change from a unique regional perspective delivering stateof-art knowledge that can be pivotal not only from a scientific but from decision-making, and thus a policy-oriented perspective. It can be recommended that the topic of climate innovation and Climate-Smart Agriculture must be included in the curricula of the Digital Academy of Agriculture, thus providing a framework for existing digital curricula and their dissemination in Hungary and abroad, so that all actors in agriculture can acquire basic digital skills. In the second phase of the DAA, we recommend the inclusion of ClimateSmart Agriculture in the curriculum, which would provide a framework for existing digital solutions, thus helping to increase the level of digital maturity in Hungarian agriculture.

Author Contributions: Conceptualization, K.B. and M.S.C.; methodology, M.S.C. and K.B.; validation, M.S.C., B.N. and K.B.; formal analysis, K.B.; investigation, K.B. and M.S.C.; resources, M.S.C., B.N. and K.B.; data curation, K.B.; writing-original draft preparation, K.B.; writing-review and editing, K.B. and M.S.C.; visualization, M.S.C. and K.B.; supervision, M.S.C. and B.N.; project administration, B.N.; funding acquisition, B.N. All authors have read and agreed to the published version of the manuscript.

Funding: This research received no external funding.

Institutional Review Board Statement: Not applicable.

Informed Consent Statement: Not applicable.

Data Availability Statement: The Hungarian GDP and emissions data were provided by the Hungarian Central Statistical Office [53]. The DESI data was provided by the European Commission database [19]. The global anthropogenic GHG emissions data was provided by IPCC [3].

Acknowledgments: This paper was supported by the János Bolyai Research Scholarship of the Hungarian Academy of Sciences. The research reported in this paper and carried out at the Budapest University of Technology and Economics has been supported by the National Research Development and Innovation Fund (TKP2020 Institution Excellence Subprogram, Grant No. BME-IE-MISC) based on the charter of bolster issued by the National Research, Development, and Innovation Office under the auspices of the Ministry for Innovation and Technology. Supported by the UNNP-21-5 New National Excellence Program of the Ministry for Innovation and Technology from the source of the National Research, Development, and Innovation Fund.

Conflicts of Interest: The authors declare no conflict of interest. 


\section{References}

1. WWF. Enabling the Transition: Climate Innovation Systems for a Low-Carbon Future; WWF: Stockholm, Sweden, 2011; 132p, ISBN 978-91 89272-19-4.11.002.

2. IPCC. 2021: Summary for Policymakers. In Climate Change 2021: The Physical Science Basis. Contribution of Working Group I to the Sixth Assessment Report of the Intergovernmental Panel on Climate Change; Masson-Delmotte, V., Zhai, A.P., Pirani, S.L., Connors, C., Péan, S., Berger, N., Caud, Y., Chen, L., Goldfarb, M.I., Huang, K.M., et al., Eds.; Cambridge University Press: Cambridge, UK, 2021; Available online: https://www.ipcc.ch/report/ar6/wg1/downloads/report/IPCC_AR6_WGI_Full_Report.pdf (accessed on 2 August 2021).

3. IPCC. 2019: Climate Change and Land: An IPCC Special Report on Climate Change, Desertification, Land Degradation, Sustainable Land Management, Food Security, and Greenhouse Gas Fluxes in Terrestrial Ecosystems; Shukla, P.R., Skea, J., Buendia, E.C., MassonDelmotte, V., Pörtner, H.-O., Roberts, D.C., Zhai, P., Slade, R., Connors, S., van Diemen, R., et al., Eds.; Cambridge University Press: Cambridge, UK, 2019.

4. Bosello, F. The role of economic modelling for climate change mitigation and adaptation strategies. In Routledge Handbook of the Economics of Climate Change Adaptation; Markandya, A., Galarraga, I., de Murieta, E.S., Eds.; Routledge: Abingdon, UK, 2014. [CrossRef]

5. Porter, J.R.; Xie, L.; Challinor, A.J.; Cochrane, K.; Howden, S.M.; Iqbal, M.M.; Lobell, D.B.; Travasso, M.I. Food security and food production systems. In Climate Change 2014: Impacts, Adaptation, and Vulnerability. Part A: Global and Sectoral Aspects. Contribution of Working Group II to the Fifth Assessment Report of the Intergovernmental Panel on Climate Change; Field, C.B., Barros, V.R., Dokken, D.J., Mach, K.J., Mastrandrea, M.D., Bilir, T.E., Chatterjee, K.L.M., Ebi, Y.O., Estrada, R.C., Genova, B., et al., Eds.; Cambridge University Press: Cambridge, UK; New York, NY, USA, 2014; pp. 485-533.

6. Biesbroek, G.R.; Termeer, C.J.A.M.; Klostermann, J.E.M.; Kabat, P. On the nature of barriers to climate change adaptation. Reg. Environ. Chang. 2013, 13, 1119-1129. [CrossRef]

7. Isoard, S. Perspectives on adaptation to climate change in Europe. In Climate Change Adaptation in Developed Nations; Ford, J.-D., Berrang-Ford, L., Eds.; Springer: Dordrecht, The Netherlands, 2011; pp. 51-68. [CrossRef]

8. Moser, S.C. Adaptation, mitigation and their disharmonious discontents: An essay. Clim. Chang. 2011, 111, 165-175. [CrossRef]

9. Chavas, R.D.; Izaurraldea, R.C.; Thomson, A.M.; Gao, X. Long-term climate change impacts on agricultural productivity in eastern China. Agric. For. Meteorol. 2009, 149, 1118-1128. [CrossRef]

10. Hatfield, J.L.; Prueger, J.H. Temperature extremes: Effect on plant growth and development. Weather. Clim. Extrem. 2015, 10, 4-10. [CrossRef]

11. Olesen, J.; Bindi, M. Consequences of climate change for European agricultural productivity, land use and policy. Eur. J. Agron. 2002, 16, 239-262. [CrossRef]

12. Vanschoenwinkel, J.; Mendelsohn, R.; Van Passel, S. Do Western and Eastern Europe have the same agricultural climate response? Taking adaptive capacity into account. Glob. Environ. Chang. 2016, 41, 74-87. [CrossRef]

13. Qi, L.; Bravo-Ureta, B.E.; Cabrera, V.E. From cold to hot: Climatic effects and productivity in Wisconsin dairy farms. J. Dairy Sci. 2015, 98, 8664-8677. [CrossRef] [PubMed]

14. Abildtrup, J.; Audsley, E.; Fekete-Farkas, M.; Giupponi, C.; Gylling, M.; Rosato, P.; Rounsevell, M. Socio-economic scenario development for the assessment of climate change impacts on agricultural land use: A pairwise comparison approach. Environ. Sci. Policy 2006, 9, 101-115. [CrossRef]

15. European Environment Agency. Climate Change Adaptation in the Agriculture Sector in EUROPE; EEA Report No 04/2019; Publications Office of the European Union: Luxembourg, 2019; p. 112. [CrossRef]

16. DESI. 2020. Available online: https:/ / ec.europa.eu/digital-single-market/en/digital-economy-and-society-index-desi (accessed on 28 March 2021).

17. European Innovation Scoreboard (EIS). Country Profiles: Hungary. 2020. Available online: https:/ / ec.europa.eu/commission/ presscorner/detail/en/QANDA_20_1150 (accessed on 28 March 2021).

18. Esses, D.; Csete, M.S.; Németh, B. Sustainability and Digital Transformation in the Visegrad Group of Central European Countries. Sustainability 2021, 13, 5833. [CrossRef]

19. Szőke, V.; Kovács, L. Mezőgazdaság 4.0—Relevancia, lehetőségek, kihívások. Gazdálkodás 2020, 64, 289-304. Available online: https:/ / ageconsearch.umn.edu/record/305196 (accessed on 10 June 2021).

20. Bartholy, J.; Pongracz, R.; Torma, C.; Pieczka, I.; Kardos, P.; Hunyady, A. Analysis of regional climate change modelling experiments for the Carpathian Basin. Int. J. Glob. Warm. 2009, 1, 238-252. [CrossRef]

21. Torma, C.; Coppola, E.; Giorgi, F.; Bartholy, J.; Pongrácz, R. Validation of a high-resolution version of the regional climate model RegCM3 over the Carpathian basin. J. Hydrometeorol. 2011, 12, 84-100. [CrossRef]

22. Kis, A.; Pongrácz, R.; Bartholy, J. Multi-model analysis of regional dry and wet conditions for the Carpathian Region. Int. J. Climatol. 2017, 37, 4543-4560. [CrossRef]

23. Reilly, J.; Schimmelpfennig, D. Agricultural impact assessment, vulnerability, and the scope for adaptation. Clim. Chang. 1999, 43, 745-788. [CrossRef]

24. Hartmann, B.; Börcsök, E.; Groma, V.O.; Osán, J.; Talamon, A.; Török, S.; Alföldy-Boruss, M. Multi-criteria revision of the Hungarian Renewable Energy Utilization Action Plan-Review of the aspect of economy. Renew. Sustain. Energy Rev. 2017, 80, 1187-1200. [CrossRef] 
25. Smit, B.; McNabb, D.; Smithers, J. Agricultural adaptation to climatic variation. Clim. Chang. 1996, 33, 7-29. [CrossRef]

26. Bryant, C.R.; Smit, B.; Brklacich, M.; Johnston, T.R.; Smithers, J.; Chiotti, Q.; Singh, B. Adaptation in Canadian Agriculture to Climatic Variability and Change. Clim. Chang. 2000, 45, 181-201. [CrossRef]

27. Biró, K.; Szalmáné Csete, M. Corporate social responsibility in agribusiness: Climate-related empirical findings from Hungary. Environ. Dev. Sustain. 2021, 23, 5674-5694. [CrossRef]

28. Jankó, F.; Németh, N.; Bertalan, L.; Pappne, V.J. Perceptions of climate change and adaptation in Hungarian agriculture: Results of an interview study. Stud. Agric. Econ. 2017, 119, 55-61. [CrossRef]

29. Farkasné Fekete, M. A mezőgazdasági területek érzékenységének és adaptációs képességének mérési lehetőségei. Gazdálkodás 2009, 53, 222-232. Available online: https://ageconsearch.umn.edu/record/92481/files/FarkasneFeketeM.pdf (accessed on 10 June 2021).

30. Gaál, M.; Molnar, A.; Illés, I.; Kiss, A.; Lámfalusi, I.; Kemény, G. Where Do We Stand with Digitalization? An Assessment of Digital Transformation in Hungarian Agriculture; Academic Press: Waltham, MA, USA, 2021. [CrossRef]

31. Gaál, M.; Quiroga, S.; Fernandez-Haddad, Z. Potential impacts of climate change on agricultural land use suitability of the Hungarian counties. Reg. Environ. Chang. 2014, 14, 597-610. [CrossRef]

32. Jolánkai, M.; Birkás, M. Global climate change impacts on crop production in Hungary. Agric. Conspec. Sci. 2007, 72, 17-20. Available online: https://www.academia.edu/20881120/Global_Climate_Change_Impacts_on_Crop_Production_in_Hungary (accessed on 15 January 2020).

33. Li, S.; Juhász-Horváth, L.; Harrison, P.A.; Pintér, L.; Rounsevell, M.D.A. Relating farmer's perceptions of climate change risk to adaptation behaviour in Hungary. J. Environ. Manag. 2017, 185, 21-30. [CrossRef] [PubMed]

34. Li, S.; Juhász-Horváth, L.; Pintér, L.; Rounsevell, M.D.A.; Harrison, P.A. Modelling regional cropping patterns under scenarios of climate and socio-economic change in Hungary. Sci. Total Environ. 2018, 622-623, 1611-1620. [CrossRef]

35. Zemankovics, M.H. Mitigation and adaptation to climate change in Hungary. J. Cent. Eur. Agric. 2012, 13, 58-72. [CrossRef]

36. Darwin, R. Effects of Greenhouse Gas Emissions on World Agriculture, Food Consumption, and Economic Welfare. Clim. Chang. 2019, 66, 191-238. [CrossRef]

37. Johnson, J.M.-F.; Franzluebbers, A.J.; Weyers, S.L.; Reicosky, D.C. Agricultural opportunities to mitigate greenhouse gas emissions. Environ. Pollut. 2007, 150, 107-124. [CrossRef]

38. Shurpali, N.; Agarwal, A.K.; Srivastava, V. (Eds.) Greenhouse Gas Emissions; Elsevier Inc.: Amsterdam, The Netherlands, 2019. [CrossRef]

39. Smith, P.; Martino, D.; Cai, Z.; Gwary, D.; Janzen, H.; Kumar, P.; Rice, C. Policy and technological constraints to implementation of greenhouse gas mitigation options in agriculture. Agric. Ecosyst. Environ. 2007, 118, 6-28. [CrossRef]

40. Branca, G.; McCarthy, N.; Lipper, L.; Jolejole, M.C. Climate-Smart Agriculture: A Synthesis of Empirical Evidence of Food Security and Mitigation Benefits from Improved Cropland Management. 2011. Available online: http://www.fao.org/3/i2574e/i2574e00. pdf (accessed on 10 January 2021).

41. Frühauf, M.; Guggenberger, G.; Meinel, T.; Theesfeld, I.; Lentz, S. (Eds.) KULUNDA: Climate Smart Agriculture; Innovations in Landscape Research; Springer Nature: Cham, Switzerland, 2020. [CrossRef]

42. Khatri-Chhetri, A.; Pant, A.; Aggarwal, P.K.; Vasireddy, V.V.; Yadav, A. Stakeholders' prioritization of climate-smart agriculture interventions: Evaluation of a framework. Agric. Syst. 2019, 174, 23-31. [CrossRef]

43. Lipper, L.; McCarthy, N.; Zilberman, D.; Asfaw, S.; Branca, G. (Eds.) Climate Smart Agriculture; Springer International Publishing: Cham, Switzerland, 2018; Volume XVIII, p. 630. [CrossRef]

44. Obi, A.; Maya, O. Innovative Climate-Smart Agriculture (CSA) Practices in the Smallholder Farming System of South Africa. Sustainability 2021, 13, 6848. [CrossRef]

45. KSH GDP and Its Distribution by Industry. 2021. Available online: http://www.ksh.hu/stadat_files/gdp/hu/gdp0006.html (accessed on 20 June 2021).

46. Csete, L. Kihívás: A fenntarthatóság megvalósítása vidéken. Gazdálkodás Agrárökonómiai Tudományos Folyóirat 2010, 54, 148-159.

47. IICA. Innovation in Agriculture: A Key Process for Sustainable Development; Institutional Position Paper: San Jose, CA, USA, 2014; Available online: https:/ / repositorio.iica.int/bitstream/handle/11324/2607/BVE17038694i.pdf?sequence=1 (accessed on 10 February 2021).

48. IICA and IDB (InterAmerican Development Bank). Impactful Innovations: Lessons from Family Agriculture in Latin America and the Caribbean; IICA and IDB (InterAmerican Development Bank): San Jose, CA, USA, 2013; ISBN 978-92-9248-514-6.

49. Diez, M.A. The Evaluation of Regional Innovation and Cluster Policies: Towards a Participatory Approach. Eur. Plan. Stud. 2001, 9, 907-923. [CrossRef]

50. Cofré-Bravo, G.; Klerkx, L.; Engler, A. Combinations of bonding, bridging, and linking social capital for farm innovation: How farmers configure different support networks. J. Rural. Stud. 2019, 69, 53-64. [CrossRef]

51. Molina, N.; Brunori, G.; Favilli, E.; Grando, S.; Proietti, P. Farmers' Participation in Operational Groups to Foster Innovation in the Agricultural Sector: An Italian Case Study. Sustainability 2021, 13, 5605. [CrossRef]

52. Csete, L. A hatékonyság társadalmi, gazdasági jelentősége és változó megítélése. In Debreceni Egyetem Agrártudományi Centrum által rendezett tudományos ülés: Az agrárinnovációtól a társadalmi aszimmetriákig; Center-Print: Debrecen, Hungary, 2006 ; pp. 272-287. 
53. EIP-AGRI. Agricultural Knowledge and Innovation Systems—Stimulating Creativity and Learning; European Commission: Brussels, Belgium, 2018; Available online: https://ec.europa.eu/eip/agriculture/sites/default/files/eip-agri_brochure_knowledge_ systems_2018_en_web.pdf (accessed on 20 March 2021).

54. FAO. CLIMATE-SMART AGRICULTURE Sourcebook; FAO: Rome, Italy, 2013; ISBN 978-92-5-107720-7. Available online: http: //www.fao.org/3/i3325e/i3325e.pdf (accessed on 2 September 2020).

55. Beddington, J.; Asaduzzaman, M.; Clark, M.; Fernández, A.; Guillou, M.; Jahn, M.; Erda, L.; Mamo, T.; Van Bo, N.; Nobre, C.A.; et al. Achieving Food Security in the Face of Climate Change: Final Report from the Commission on Sustainable Agriculture and Climate Change; CGIAR Research Program on Climate Change: Copenhagen, Denmark; Agriculture and Food Security (CCAFS): Copenhagen, Denmark, 2012; Available online: www.ccafs.cgiar.org/commission (accessed on 10 June 2020).

56. FAO. "Climate-Smart" Agriculture: Policies, Practices and Financing for Food Security, Adaptation, and Mitigation; FAO: Rome, Italy, 2010; Available online: http://www.fao.org/3/i1881e/i1881e00.pdf (accessed on 10 December 2020).

57. Foresight. The Future of Food and Farming: Challenges and Choices for Global Sustainability; Final Project Report; The Government Office for Science: London, UK, 2011; Available online: http:/ /www.eracaps.org/sites/default/files/content/foresight_report. pdf (accessed on 2 June 2021).

58. High Level Panel of Experts (HLPE). Food Security and Climate Change. A Report by the HLPE on Food Security and Nutrition of the Committee on World Food Security; HLPE: Rome, Italy, 2012; Available online: http:/ /www.fao.org/fileadmin/user_upload/hlpe/ hlpe_documents/HLPE_Reports/HLPE-Report-3-Food_security_and_climate_change-June_2012.pdf (accessed on 10 June 2020).

59. Sova, C.A.; Grosjean, G.; Baedeker, T.; Nguyen, T.N.; Wallner, M.; Jarvis, A.; Nowak, A.; Corner-Dolloff, C.; Girvetz, E.; Laderach, P.; et al. Bringing the Concept of Climate-Smart Agriculture to Life: Insights from CSA Country Profiles Across Africa, Asia, and Latin America; World Bank: Washington, DC, USA; The International Centre for Tropical Agriculture: Washington, DC, USA, 2018; p. 36.

60. World Bank. Kazakhstan PROGRAM FOR RESULTS, Sustainable Livestock Development Program in Kazakhstan (P170365) Environmental and Social Systems Assessment (ESSA). 2020. Available online: https:/ / documents1.worldbank.org/curated/en/ 395041594000839239/pdf/Kazakhstan-Sustainable-Livestock-Development-Program-for-Results.pdf (accessed on 2 July 2021).

61. Raftowicz, M.; Kalisiak-Mędelska, M.; Stru's, M. The Implementation of CSA Model in Aquaculture Management in Poland. Sustainability 2021, 13, 1242. [CrossRef]

62. Kernecker, M.; Knierim, A.; Wurbs, A.; Kraus, T.; Borges, F. Experience versus expectation: Farmers' perceptions of smart farming technologies for cropping system across Europe. Precis. Agric. 2020, 21, 34-50. [CrossRef]

63. Tadesse, M.; Simane, B.; Abera, W.; Tamene, L.; Ambaw, G.; Recha, J.W.; Mekonnen, K.; Demeke, G.; Nigussie, A.; Solomon, D. The Effect of Climate-Smart Agriculture on Soil Fertility, Crop Yield, and Soil Carbon in Southern Ethiopia. Sustainability 2021, 13, 4515. [CrossRef]

64. Farkas, G.; Magyar, P.; Molnár, A.; Zubor-Nemes, A. Adatbányászati módszerek alkalmazás a mezőgazdaságban—A gépi tanulás felhasználási lehetőségei. Gazdálkodás Sci. J. Agric. Econ. 2020, 64, 15-24. [CrossRef]

65. Gáborné, J.Á.; Varga, Z.; Vér, A. AKIS Country Report HUNGARY. Hungarian Chamber of Agriculture, Széchenyi István University January 2021, Version 2. Available online: http:/ / www.nak.hu/images/i2connect_AKIScountryreport_HUNGARYFINAL-2021_01_12-EN-v2.pdf (accessed on 2 August 2021). 